\title{
National Innovation Infrastructure in the Context of Digital Transformation
}

\author{
Sirotkina N.V.* \\ Voronezh State Technical University \\ Voronezh, Russia \\ docsnat@yandex.ru
}

Goncharov A.Yu.

Voronezh State Medical University named after

N.N. Burdenko

Voronezh, Russia

alex.g007@mail.ru

\author{
Kiselev S.S. \\ Voronezh State University \\ Voronezh, Russia \\ serge_kiselev@bk.ru
}

\begin{abstract}
The tasks of energy management of the subjects of the national economy of Russia are associated with the state economy and the natural ecosystem of the world. It is necessary to develop an interest in innovations, otherwise the process of introducing innovations is accompanied by resistance. Public figures may be obligated to introduce innovation. At present, the attitude of individuals to innovation is completely different. It is necessary to prove economic efficiency to increase the level of consumer loyalty of individuals. National innovation infrastructure may be a component in the organization of energy management in Russia. This structure allows involving individuals in the process of innovation. Digital technologies allow organizing digital interaction to develop energy management through a network of national innovation infrastructure. Thus, we can obtain empirical evidence of the efficiency of energy innovation. The theoretical part of the research is described in the paper. This part was compiled using information and knowledge about the national innovation infrastructure. The schemes for the implementation of energy management in Russia were submitted in this document.
\end{abstract}

Keywords - energy management, innovation infrastructure, digital economy, energy innovation.

\section{INTRODUCTION}

The relevance of the topic of research on the role of national innovation infrastructure in energy management in the context of digitalization is justified by the need for the widespread introduction of energy management system. It's related to the state of Russia's economy and the state of the natural ecosystem.

The documents of the Russian authorities and the works of scientists and researchers: A. Gorokhova, V. Sekerin [19], M. Gladkih [20], N. Sirotkina [8], S. Kiselev [20], T. Tolstykh [23-25], D. Savon [26-29], G. Khmeleva [30-32], E. Shkarupeta [33-35] are the theoretical basis of this research.

\author{
Gladkih M.O. \\ Voronezh State University \\ Voronezh, Russia \\ gladkih_maksim3@list.ru
}

Panchenko V.E.

Voronezh State University

Voronezh, Russia

v.e.panchenko@gmail.com

\author{
Batova A.V. \\ Voronezh State Technical University \\ Voronezh, Russia \\ avbatova@vgasu.vrn.ru
}

The scientific hypothesis of the research is based on the underlying assumption that the national innovation infrastructure could be the driver of the development of energy management system in the context of digitalization [1,2].

The research aims to develop theoretical principles for the organization of energy management system in Russia through the national innovation infrastructure in the context of digitalization [3]

The research object is the process of the organization of the energy management system in Russia. The research subject is the social and economic relations of the entities of national innovation infrastructure in the context of digitalization.

The innovative nature of the research results is to define the place of the national innovation infrastructure in the organization of the energy management system in Russia.

The theoretical research impact is to justify the provisions clarifying the place of the national innovation infrastructure in the process of organizing the energy management system in Russia.

\section{METHODS AND MATERIALS}

The materials from available Internet sources and print sources are used in this research: materials from the Russian President's official website, the Ministry of Economic Development of Russia, the Ministry of Digital Development, Communications and Mass Media of the Russian Federation, the Russian Congress Foundation, the Association of Accelerators and Business Incubators of Russia, Russia's Scientific Electronic Library LLC (eLIBRARY.RU); monograph and conference materials.

We have considered a separate category demonstrated it in a single process of organization of the energy management 
system in Russia through a national innovation infrastructure using analysis and synthesis methods. The application of the scientific abstraction method has helped to make a connection between the energy management system, the national innovation infrastructure, and the digital economy. By deduction, we have established a link between innovation infrastructure and energy innovation. Building from the experience of the previous researchers, we have used the heuristic method [4]. In addition, we have used methods for summarizing scientific facts and studying literature, documents, and performance.

\section{RESULTS}

First of all, the realization of the organization of the energy management system in Russia should be stated from the property complexes of the innovation infrastructure of state and municipal ownership changes. The mechanisms of municipal-private partnerships and public-private partnerships should be applied in the process of the organization [5]. The organization order is shown in Figure 1. National innovation infrastructure is the core of the energy management system in Russia.

Property complexes of the innovative infrastructure of state and municipal ownership

Property complexes of state and municipal ownership

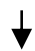

Property complexes of innovation infrastructure - objects of the agreement on public-private partnership or municipal-private partnership

Property complexes - objects of the agreement on public-private partnership or municipal-private partnership

Property complexes of innovation infrastructure of private ownership

Property complexes of private ownership

Fig. 1. Generalized organization of the energy management system in Russia

Figure 2 showed the algorithm for testing energy innovations in property complexes of the innovative infrastructure of state and municipal ownership.

The subjects of the national innovation infrastructure are in digital interaction in the testing processes [6]. Testing results are entered into the database and are available to owners of property complexes.

\section{DISCUSSION}

Energy efficiency, energy conservation, and environmental management are included in the priority areas for the development of science, technology, and technology to modernize and technological development of the Russian economy and improving its competitiveness [7]. The strategic development plan of the Russian Federation includes activities to improve energy efficiency and reduce the consumption of fuel and energy resources. The energy efficiency of the economy is an important element of sustainable development. The implementation of energy conservation and energy efficiency projects are included in the mechanisms for achieving sustainable environmental development [9]. Tasks to increase energy efficiency, reduce the energy intensity of the Russian economy [10], promote innovative and digital development of the fuel and energy complex, reduce the anthropogenic impact of the fuel and energy complex on the environment [11] are included in state programs.

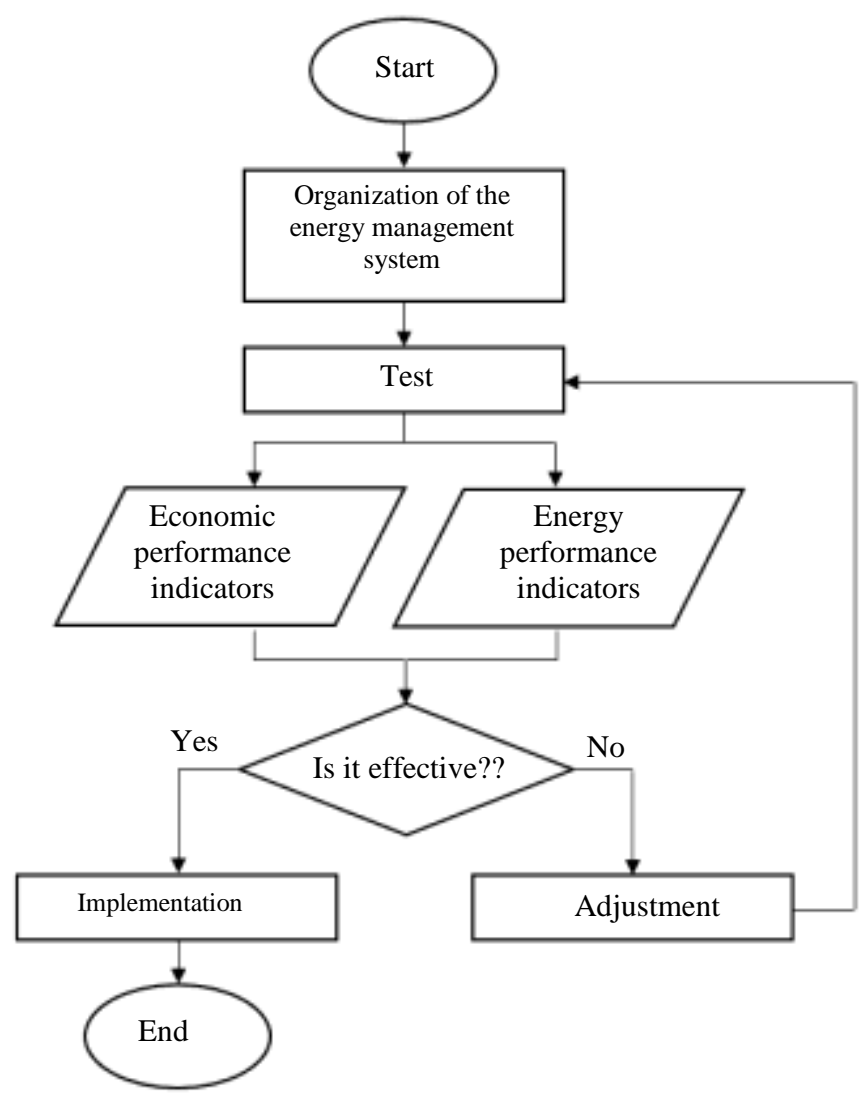

Fig. 2. Algorithm for energy innovation testing

The measures for the organization of energy management concerning property complexes of state and municipal ownership and multi-apartment buildings - the creation of universal digital platforms for inventory, accounting and monitoring the status of all types of energy resources are provided for by the National Program "Digital Economy in the Russian Federation". Currently, state authorities, local governments, state and municipal institutions are obligated to keep a record on energy consumption [12].

Energy conservation and energy efficiency were one of the most discussed topics at the international forum "Russian Energy Week-2019". In addition, the above areas are recognized as fuel and energy development trends [13].

In early works, we have noted the negative impact of low levels of energy efficiency on the Russian economy. This impact has expressed in a decrease in the competitiveness of the economy. In addition, the energy capacities are necessary for the implementation of the breakthrough scenario of the socio-economic development of Russia. The energy capacities 
are not used at the expense of ensuring energy efficiency and achieving energy conservation. The society will pay 4 times less for the implementation of the energy efficiency and energy conservation strategy than for the construction of new power plants [14]. The depletion of natural resources and adverse changes in the natural ecological system is one of the problems of energy efficiency.

Today, energy innovation research is a popular topic among researchers. A brief study of the materials of the public scientific library revealed several types of energy innovation in various subjects of the scientific infrastructure [15]. The list is shown in table 1. It is beyond doubt that a deeper analysis of various sources could give much more results. Thus, there are a sufficient number of different energy innovations that require testing. Thus, the energy innovation means the innovations of any kind aimed at solving the problems of energy efficiency and energy conservation.

TABLE I. DETECTED ENERGY INNOVATIONS [16-18]

\begin{tabular}{|l|l|}
\hline \multicolumn{1}{|c|}{ The subject of scientific infrastructure } & \multicolumn{1}{c|}{$\begin{array}{c}\text { Type of energy } \\
\text { innovation }\end{array}$} \\
\hline Irkutsk national research technical university & Organizational \\
\hline Russian University of Transport & Technological \\
\hline South Ural State University & Technological \\
\hline $\begin{array}{l}\text { Ryazan State Agrotechnological University Named } \\
\text { After P.A. Kostychev }\end{array}$ & Technological \\
\hline $\begin{array}{l}\text { Voronezh State University of Engineering } \\
\text { Technology }\end{array}$ & Organizational \\
\hline $\begin{array}{l}\text { Ugra State University, } \\
\text { Omsk State Technical University }\end{array}$ & $\begin{array}{l}\text { Technological, } \\
\text { organizational }\end{array}$ \\
\hline $\begin{array}{l}\text { All-Russia Research and Development Institute of } \\
\text { Agricultural Economics }\end{array}$ & Organizational \\
\hline Volgograd State Technical University & Technological \\
\hline Izhevsk State Agricultural Academy & Technological \\
\hline Voronezh State Technical University & Technological \\
\hline
\end{tabular}

The innovation climate of the innovation environment has an impact on innovation development. Consumer loyalty is one of the components of the institutional environment of the innovation climate [21]. The level of consumer loyalty to innovation determines the degree of readiness for its adoption. Environmental subjects create the environmental climate. The subject of the innovation environment is the innovation infrastructure. The servicing and facilitating innovation processes are the functions of the subject of the innovation environment. Individuals and legal entities are subject. Private types of services are material, technical, financial, organizational and methodological, information, consulting. If one of the main causes of socio-economic transformations is innovation processes, the close connection between the innovation infrastructure and the ongoing transformations becomes obvious, including the formation of a digital economy [22].

The innovation infrastructure system includes [20]:

- production and technological component;

- consulting component;

- financial component;

- human resources component;
- information component;

- marketing component.

We accept the definition of innovative infrastructure from the law [21], adjusted for the inclusion of individuals in many subjects.

The purpose of the innovation infrastructure is the development of innovation. It is the lifelong companion of the innovation infrastructure. Thus, the innovation infrastructure has a level of consumer loyalty sufficient for testing and implementing innovations for subsequent replication and commercialization. Possible forms of ownership of innovation infrastructure are shown in Figure 3.

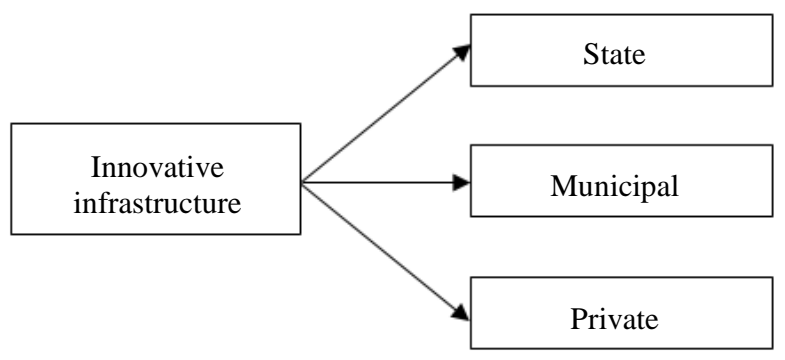

Fig. 3. Forms of ownership of innovation infrastructure

The owners of municipal and state property have to be obliged to test energy innovations. Thus, the organization of the energy management system in the Russian Federation should begin with property complexes of innovative infrastructure concerning state and municipal ownership.

The issues of the energy management system affect public and private interests. It is necessary to organize the energy management system in Russia using the mechanism of municipal-private partnerships and public-private partnerships.

Figure 3 shows the procedure for the organization of the energy management system in Russia. This procedure is aimed at involving the various subjects in the process of the energy management system.

First stage. The organization of the energy management system begins with testing on the property complexes of the innovative infrastructure of state and municipal ownership. Indicators of economic and energy efficiency are determined by the test results. The implementation of energy management occurs in the case of a cumulative sufficient effect. Communication between subjects is carried out through a digital platform. The platform also contains data on test results and its effectiveness.

The information should be recorded on the digital platform at every stage of the organization of the energy management system.

Second stage. Based on data from the digital platform, the energy management system is organized on the remaining property complexes of the innovative infrastructure of state and municipal ownership. Communication is carried out in the digital form. 
To the third stage, the energy management system has already been organized in all property complexes of state and municipal ownership.

The involvement of individuals in the process of energy management system through loyal individuals - the innovative infrastructure begins at the third stage. Experience has already been accumulated and there are arrays of data on trials and efficacy. Additional consumer loyalty is increased by reducing costs for individuals due to the mechanism of public-private partnership.

At the fourth stage, the energy management system is organized on the remaining property complexes - objects of the public-private partnership agreement.

The fifth and sixth stages are aimed at the full involvement of individuals in the process of energy management in Russia.

To further reduce the negative impact of economic activity on the environment, the best available technologies should be applied in the organization of the energy management system at specific entities of the national innovation infrastructure.

Today, five types of innovation infrastructure are institutionalized in Russia. The total number is 633 elements. [23]. However, the list of types is not complete, since any person becomes the element of the multitude of national innovation infrastructure from the moment of assistance to innovative projects. Thus, the total number of activities is unclear and continual regarding all individuals and legal entities of Russia. Therefore, to test any innovation, the subject of the national innovation infrastructure with the necessary resources can always be found.

The conditions for digitalization lie in the digital (virtual) socio-economic relations. Universal digital platforms for the inventory, accounting, and control of the state of all types of energy resources created as part of the state program [5] are an official manifestation of the digital economy.

The subjects of the national innovation infrastructure are scattered throughout Russia. In the context of digitalization, the digital (virtual) structure can be created to test energy innovations and integrate with the digital platform. It will allow building national cooperation on the development of the energy management system and gathering an empirical basis for proving the effectiveness of energy innovations.

\section{CONCLUSION}

The energy management system is one of the factors in the development of the Russian economy. In addition, solving the problems of energy efficiency and energy conservation contributes to the preservation of the natural ecological system. The energy management system is the object of interest for researchers, and today there is an extensive base of energy innovations that require testing.

The owners of property complexes are obligated to have a certain level of consumer loyalty to energy innovation for the development of the energy management system at the national level. Innovative infrastructure has the level of consumer loyalty sufficient for testing and implementing innovations for subsequent replication and commercialization.
The organization of the energy management system in the Russian Federation should be begun with property complexes of the innovative infrastructure of state and municipal ownership. It would make sense to organize the energy management system in Russia using the mechanisms of municipal-private partnerships and public-private partnerships.

Many of the national innovation infrastructures are unclear and contiguous concerning all individuals and legal entities in Russia. The conditions for digitalization lie in digitize of (digital transformation) socio-economic relations. The role of the national innovation infrastructure in the development of the energy management system in the context of digitalization consists in digital interaction to test innovations. Testing results form the basis of empirical evidence of the effectiveness of energy innovation. The validity of efficiency increases the consumer loyalty of individuals and involves it in energy management processes.

\section{References}

[1] M. Zheng, G.-F. Feng, S. Feng, X. Yuan, "The road to innovation vs. the role of globalization: A dynamic quantile investigation", Econ. Modell., vol. 83, pp. 65-83, 2019. Retrieved from: https://doi.org/10.1016/j.econmod.2019.09.019.

[2] S. Szambelan, Y. Jiang, R. Mauer, "Breaking through innovation barriers: Linking effectuation orientation to innovation performance", Europ. Manag. J., 2019. Retrieved from: https://doi.org/10.1016/j.emj.2019.11.001.

[3] B. Lin, R. Luan, "Are government subsidies effective in improving innovation efficiency? Based on the research of China's wind power industry", Sci. of The Total Environment, vol. 710, 2020. Retrieved from: https://doi.org/10.1016/j.scitotenv.2019.136339.

[4] D. Loorbach, J. Wittmayer, F. Avelino, T. von Wirth, N. Frantzeskaki, "Transformative innovation and translocal diffusion", Environmental Innovat. and Societal Transit., 2020. Retrieved from: https://doi.org/10.1016/j.eist.2020.01.009.

[5] A. Pustovrh, K. Rangus, M. Drnovšek, "The role of open innovation in developing an entrepreneurial support ecosystem", Technol. Forecast. and Soc. Change, vol. 152, 2020. Retrieved from: https://doi.org/10.1016/j.techfore.2019.119892.

[6] M. Cucculelli, V. Peruzzi, "Innovation over the industry life-cycle. Does ownership matter?", Res. Policy, vol. 49, no. 1, 2020. Retrieved from: https://doi.org/10.1016/j.respol.2019.103878.

[7] Y. Salikov, I. Logunova, I. Kablashova, "Trends in human resource management in the digital economy", Proc. of the Voronezh State Univer. of Engineer. Technol., vol. 81, no. 2, pp. 393-399, 2019. Retrieved from: https://doi.org/10.20914/2310-1202-2019-2-393-399.

[8] N. Sirotkina, O. Stukalo, N. Nikitina, M. Filatova, "Crises and digital economy: The territorial aspect of the problem of networking of stakeholders in the food markets", Advan. in Intellig. Syst. and Comput. vol. 908, pp. 686-692, 2020

[9] V. Gorbunova, E. Puzina, "Efficiency of Implementing the Energy Management System in Industrial Companies of Russia", Transport Syst. and Technol., vol. 1, pp. 119-137, 2018. DOI: 10.17816/transsyst2018041119-137.

[10] V. Podsorin, M. Tereshin, O. Chuverina, "The Economic Potential of Measures to Improve Energy Efficiency in the Field of Railway Transport", Transport busin. of Russ., vol. 1, pp. 12-14, 2019.

[11] A. Dzuba, I. Solovieva, "Integration of demand management systems for electricity and gas with a small distributed generation of an industrial enterprise", Bull. of Tomsk State Univer., Econ., vol. 45, pp. 216-233, 2019. DOI: $10.17223 / 19988648 / 45 / 15$.

[12] A. Manin, D. Makarov, "Topological method of analysis of distribution networks", Bull. of Sci., vol. 2-2, no. 11, pp. 116-123.

[13] O. Lukina, V. Dudchak, "The integrated approach to the development of innovative activities, taking into account the synergistic effect", Bull. of 
the Voronezh State Techn. Univer., vol. 80, no. 3, pp. 423-428, 2018. DOI: $10.20914 / 2310-1202-2018-3-423-428$

[14] O. Arkhipova, V. Kovalev, R. Khamitov, "Methodology for modeling a regionally isolated electrical complex", Bull. of the Tomsk Polytech Univer.. Geo-Resource Engineer., vol. 330-1, pp. 173-180, 2019. DOI: 10.18799/24131830/2019/1/63.

[15] V. Kruchinina, S. Ryzhkova, "Cooperatives in the field of agricultural energy supply (taking into account foreign experience)", Bull. of the Voronezh State Univer. of Engineer. Technol., vol. 81, no. 1, pp. 470 479, 2019. DOI: 10.20914/2310-1202-2019-1-470-479.

[16] A. Sokolov, A. Tukov, M. Shcherbakov, T. Yanovsky, "Multilevel architecture of the system of intellectual support for managerial decision-making in resource-providing systems of industrial production", Model., optimizat., and inform. Technol., vol. 7-1, no. 24, pp. 352-362. DOI: 10.26102/2310-6018/2019.24.1.027.

[17] D. Vasiliev, L. Panteleeva, P. Pokoev, V. Noskov, "Energy-efficient control of an asynchronous electric motor", Bull. of Nizhny Novgorod State Engineer. and Econ. Instit., vol. 4, no. 95, pp. 100-115, 2019.

[18] R. Sheps, A. Shashin, M. Zherlykina, V. Shichkin, "Determining the energy efficiency of mechanical ventilation with the release of harmful substances", vol. 2, no. 9, pp. 62-68, 2019.

[19] V. Sekerin, A. Gorokhova, "Innovation environment as a factor in the effectiveness of the commercialization of innovations", vol. 2, no. 20, p. 42,2014

[20] M. Gladkih, S. Kiselev, "The basis for the functioning of innovative infrastructure in the context of the formation of a digital economy", Socio-economic, institutional and market transformations in the contex of the formation of a digital economy, pp. 35, February 2019 [Int. Sci. and Pract. Conf.].

[21] M. Vidmar, A. Rosiello, N. Vermeulen, R. Williams, J. Dines, "New Space and Agile Innovation: Understanding transition to open innovation by examining innovation networks and moments", Acta Astronautica, vol. 167, pp. 122-134, 2020. Retrieved from: https://doi.org/10.1016/j.actaastro.2019.09.029.

[22] M. Saunila, "Innovation capability in SMEs: A systematic review of the literature", J. of Innovat. \& Knowledge, 2019. Retrieved from: https://doi.org/10.1016/j.jik.2019.11.002.

[23] T. Tolstykh, Y. Kostuhin, A. Zhaglovskaya, E. Shkarupeta, N. Andryashina, Formation of the ecosystem as a factor in the development of industrial enterprises in the digital economy, Lecture Notes in Networks and Systems Growth Poles of the Global Economy: Emergence, Changes and Future Perspectives, pp. 1247-1254, 2020.

[24] T. Tolstykh, Y. Kostuhin, A. Zhaglovskaya, E. Shkarupeta, A. Garin, Scenarios for the development of industrial complexes in the digital economy, Lecture Notes in Networks and Systems Growth Poles of the Global Economy: Emergence, Changes and Future Perspectives, pp. 1255-1261, 2020.

[25] T. Tolstykh, E. Alpeeva, E. Shkarupeta, T. Malkova, E. Garina, Algorithm for assessing the efficiency of innovational technologies of industrial enterprises, Lecture Notes in Networks and Systems Growth Poles of the Global Economy: Emergence, Changes and Future Perspectives, pp. 463-471, 2020.

[26] T. Tolstykh, D. Savon, E. Shkarupeta, S. Safronov, O. Savelyeva, "Digital transformation of managerial, technological and logistical processes based on formation of ecosystem of digital twins for individual systems", pp. 7751-7758, 2019 [Proc. of the 33rd Int. Business Information Management Association Conf., IBIMA 2019 Education Excellence and Innovation Management through Vision 2020].

[27] T. Tolstykh, D. Savon, E. Shkarupeta, S. Safronov, O. Savelyeva, "The digital transformation laboratory as an integral part of the national university of science and technology "misis" development strategy", pp. 8443-8452, 2019 [Proc. of the 33rd Int. Business Information Management Association Conf., IBIMA 2019: Education Excellence and Innovation Management through Vision 2020]

[28] T. Tolstykh, D. Savon, A. Safronov, E. Shkarupeta, T. Ivanochkina, "Methods and models for analysis the effectiveness of industria enterprises", pp. 7710-7722, 2018 [Proc. of the 32nd Int. Business Information Management Association Conference, IBIMA 2018 Vision 2020: Sustainable Economic Development and Application of Innovation Management from Regional expansion to Global Growth]

[29] T. Tolstykh, D. Savon, A. Safronov, E. Shkarupeta, T. Ivanochkina, "Economic transformations based on competence approach in the digital age”, pp. 7723-7729, 2018 [Proc. of the 32nd Int. Business Information Management Association Conf., IBIMA 2018 - Vision 2020: Sustainable Economic Development and Application of Innovation Management from Regional expansion to Global Growth].

[30] E. Shkarupeta, T. Narolina, T. Nekrasova, G. Khmeleva, "High growth industrial companies as the main agents for breakthrough development", pp. 1349-1354, 2019 [Int. Sci. Conf. Global Challenges and Prospects of the Modern Economic Development, (GCPMED 2018)]. DOI org/10.15405/EPSBS.2019.03.137.

[31] Yu. Anisimov, Yu. Zhuravlev, E. Shkarupeta, G. Khmeleva, "Breakthrough technological development of industrial enterprises amid digital transformation", pp. 1363-1370, 2019 [Int. Sci. Conf. Global Challenges and Prospects of the Modern Economic Development (GCPMED 2018). DOI: org/10.15405/EPSBS.2019.03.139.

[32] S. Sviridova, I. Kablashova, E. Shkarupeta, G. Khmeleva, "Imperative of human capital management transformation in the development of economic systems", pp. 1355-1362, 2019 [Int. Sci. Conf. Globa Challenges and Prospects of the Modern Economic Development (GCPMED 2018)]. DOI: org/10.15405/EPSBS.2019.03.138.

[33] T. Tolstykh, E. Shkarupeta, I. Purgaeva, R. Fedorenko, "Transformation of positions, competences and skills in the digital economy industry", pp. 953-959, 2019 [Int. Sci. Conf. Global Challenges and Prospects of the Modern Economic Development (GCPMED 2018)]. DOI: org/10.15405/EPSBS.2019.03.94.

[34] I. Karapetyants, Y. Kostuhin, T. Tolstykh, E. Shkarupeta, E. Syshhikova, "Transformation of logistical processes in digital economy", pp. 838-844, 2017 [Proc. of the 30th Int. Business Information Management Association Conf., IBIMA 2017 - Vision 2020: Sustainable Economic development Innovation Management, and Global Growth]

[35] I. Karapetyants, Y. Kostuhin, T. Tolstykh, E. Shkarupeta, A. Krasnikova, "Establishment of research competencies in the context of russian digitalization", pp. 845-854, 2017 [Proc. of the 30th Int. Business Information Management Association Conf., IBIMA 2017 - Vision 2020 Sustainable Economic development, Innovation Management, and Global Growth]. 